\section{Time of Interseeding of Lana Vetch and Winter Rye Cover Strips Determines Competitive Impact on Pumpkins Grown Using Organic Practices}

\author{
Steven Vanek, ${ }^{1}$ H.C. Wien, and Anu Rangarajan \\ Department of Horticulture, 134 Plant Science Building, Cornell University, \\ Ithaca, NY 14853
}

Additional index words. Vicia villosa ssp. dasycarpa, Secale cereale, Cucurbita pepo, living mulch, cover crop, organic farming

\begin{abstract}
Growing a main vegetable crop for harvest and a cover crop for residue return to soil in the same growing season is a promising strategy to sustain soil quality in vegetable rotations. Our research evaluated cover crop strips interseeded between pumpkins (Cucurbita pepo L.) as a way to implement such a strategy. Cover crop types were lana vetch (Vicia villosa ssp. dasycarpa Ten.) and a lana vetch-winter rye (Secale cereale $\mathrm{L}$.) mix, interseeded before, at the same time, or after pumpkins. The competitive impact of different cover crop strips was assessed using pumpkin yield, cover strip biomass, crop nitrogen status, soil nitrate status, and soil water potential. Cover strips were also assessed for competitiveness with native weeds. Seeding date affected the competitiveness of cover strips with pumpkins, while cover type did not. Cover crops seeded before pumpkins or at the same time reduced pumpkin yield in proportion to biomass produced by the cover strips early in pumpkin growth. Cover strips seeded after pumpkins did not reduce yield. Tilling in a before-seeded cover strip at 30 days after pumpkin seeding gave higher pumpkin yield than before-seeded cover strips that were not tilled. At three of four sites, after-seeded cover strips had the lowest percent weed biomass in strips, and at two sites with moderate weed pressure vetch-rye strips were more effective than vetch alone in suppressing weeds. Cover strips seeded before or at the same time as pumpkins reduced pumpkin yield by taking up resources that were otherwise available to pumpkins. At a high-rainfall site, competition for soil nitrate by cover crop strips was the dominant factor in reducing pumpkin yield. At a low-rainfall site, the dominant factor was competition for water. Because of effective weed suppression and lack of pumpkin yield reduction, interseeding vetch-rye strips after pumpkins was a promising practice, as was tilling in preexistent cover strips at an interval $<\mathbf{3 0}$ days after pumpkin seeding. Good previous weed management and rye-vetch mixes at high seeding rates are necessary to allow interseeded cover strips to outcompete weeds.
\end{abstract}

Cropping rotations can benefit from the inclusion of soil-improving crops. Research has documented improvements in nutrient retention and soil cover in off-season periods (Holderbaum etal., 1990; Scott etal., 1987; Yaffa et al., 2000), nutrient release to a subsequently planted vegetable crop (Abdul-Baki and Teasdale, 1993; Stivers and Shennan, 1991; Yaffa et al., 2000), weed suppression (Creamer and Bennett., 1997; Nelson et al., 1991; Stivers et al., 1999), and long-term maintenance of soil carbon and nitrogen stocks (Drinkwater et al., 2000; Puget and Drinkwater, 2001).

Because vegetable rotations are often characterized by frequent tillage, low returns of crop residue to soil, and continuous cropping for harvest and export, testing practical options for inclusion of soil-improving crops is

Received for publication 12 Mar. 2005. Accepted for publication 4 June 2005. The authors gratefully acknowledge support from the Towards Sustainability Foundation in carrying out this work. We also thank collaborating farmers Tony Potenza and Bob and the late Carol Stull for their assistance and input. This paper is part of a thesis submitted for master's degree requirements by Steven Vanek.

${ }^{1}$ To whom reprint requests should be addressed; e-mailsjv2@cornell.edu. possible spatial niche for the intercropping of cover crops that has been explored in previous research. Mohler (1995) seeded butternut squash (Cucurbita moschata Duch.) in 40-cmwide strips tilled into established white clover. Squash yield was reduced, especially in a dry year. Loy et al. (1987) investigated the effect of varying the width of a strip tilled into grass and grass-white clover living mulch crops on winter squash yield. With between-row spacing of squash constant, yield was reduced with a 0.5 -m-wide strip, but not with a 1.1-m-wide strip. This previous research utilized perennial living mulches. Interseeded annual cover crops as tested by Brainard and Bellinder (2004) with Brassica vegetables have not been evaluated with cucurbit crops.

Recognizing that yield reductions of the main crop are an obstacle to the use of interseeding, we assessed the competitive effects of interseeded annual legume (lana vetch) and grass-legume (rye-lana vetch) cover strips on pumpkin yield. We tested the date of interseeding these cover strips as a strategy for managing competition with the pumpkin crop. Suppression of weeds by the cover strips was also assessed. Rye and lana vetch were chosen as aggressive annual grass and legume species that are able to smother many weed species (Creamer and Bennett, 1997). Jack-o-lantern pumpkins, a profitable crop for direct marketing in the northeast U.S., have large leaves and rapid vine growth that was expected to match the aggressive growth of vetch and rye. We evaluated these practices in organic systems because the soil benefits of cover crops are of special interest to organic farmers.

\section{Materials and Methods}

Experiments were carried out at two university research sites under conventional (Freeville, 2001) and transitional organic (Dilmun Hill, 2000) management. Two other certified organic sites at Trumansburg and Lansing in 2001 were on cooperating farms. Each site was used for one year (Table 1). Fertility and pests were managed at all sites according to organic standards (Northeast Organic Farming Association of New York, 2001). Legume green manures did not precede the experiment at any site, so compost was applied preplant in 2000 and in a split application of preplant and side-dress in 2001 (Table 1).

Treatments were a factorial of two cover crop types and three dates of interseeding relative to the pumpkins, arranged in a randomized complete block design with four replications at each site. Cover crops were lana vetch alone (LV) or mixed lana vetch-winter rye (LV-R), seeded $20 \mathrm{~d}$ before (B), at the same time (S), and $30 \mathrm{~d}$ after (A) pumpkin seeding (LV B, LV-R B, LV S, LV-R S, LV A, and LV-R A). Treatment plots were maintained weed-free until cover crops were seeded. A weedy control(WD) without any weed management after the first cover crop seeding, and a bare ground control (BG) that was cultivated and hand-weeded throughout the season were also included. At Trumansburg and Lansing in 2001, we added before-seeded vetch-rye strips tilled in as a green manure $30 \mathrm{~d}$ after pumpkin seeding using a rotor tiller (LVR B-till). 
Table 1. Site characteristics.

\begin{tabular}{|c|c|c|c|c|c|c|c|c|}
\hline $\begin{array}{l}\text { Site } \\
\text { and } \\
\text { year }\end{array}$ & $\begin{array}{l}\text { Soil } \\
\text { series } \\
\text { and } \\
\text { type }\end{array}$ & $\begin{array}{l}\text { Soil } \\
\text { organic } \\
\text { matter } \\
(\%)\end{array}$ & $\begin{array}{c}\text { Soil } \\
\mathrm{pH}\end{array}$ & $\begin{array}{l}\text { Soil Pz } \\
\left(\mathrm{kg} \cdot \mathrm{ha}^{-1}\right)\end{array}$ & $\begin{array}{l}\text { Soil K } \\
\left(\mathrm{kg} \cdot \mathrm{ha}^{-1}\right)\end{array}$ & $\begin{array}{l}\text { Season } \\
\text { rainfally } \\
(\mathrm{mm})\end{array}$ & $\begin{array}{c}\text { Fertility } \\
\text { amendment } \\
\text { dry analysis } \\
\text { (total \% N-P-K) }\end{array}$ & $\begin{array}{l}\text { Fertility } \\
\text { amendment } \\
\text { type and } \\
\text { dry rate }\end{array}$ \\
\hline Dilmun Hill, 2000 & Hudson silty clay loam ${ }^{v}$ & 4.5 & 5.1 & 2 & 251 & 330 & $2.2-0.2-1.6$ & $\begin{array}{l}\text { Mixed food waste compost } \\
8200 \mathrm{~kg} \cdot \mathrm{ha}^{-1} \text { preplant }^{\mathrm{w}}\end{array}$ \\
\hline Freeville, 2001 & Eel silt loam ${ }^{u}$ & 2.9 & 7.4 & 59 & 31 & 420 & $3.0-2.2-2.7$ & $\begin{array}{l}\text { Chicken manure-wood chip compost } \\
3000 \mathrm{~kg} \cdot \mathrm{ha}^{-1} \text { preplant } \\
1500 \mathrm{~kg} \cdot \mathrm{ha}^{-1} \text { sidedress } 13 \mathrm{July}\end{array}$ \\
\hline Trumansburg, 2001 & Conesus silt loam ${ }^{\mathrm{t}}$ & 2.9 & 6.7 & 48 & 213 & 420 & $5.0-2.2-1.7$ & $\begin{array}{l}\text { Chicken manure compost } \\
600 \mathrm{~kg} \cdot \mathrm{ha}^{-1} \text { preplant } \\
300 \mathrm{~kg} \cdot \mathrm{ha}^{-1} \text { sidedress } 9 \mathrm{July}\end{array}$ \\
\hline Lansing, 2001 & Ovid silt loams & 3.0 & 6.2 & 3 & 125 & 320 & $5.0-2.2-2.5$ & $\begin{array}{l}\text { Chicken manure fertilizer } \\
400 \mathrm{~kg} \cdot \mathrm{ha}^{-1} \text { preplant } \\
300 \mathrm{~kg} \cdot \mathrm{ha}^{-1} \text { sidedress } 20 \mathrm{July}\end{array}$ \\
\hline
\end{tabular}

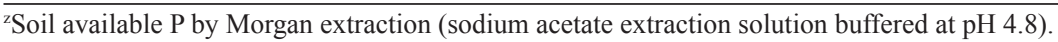

${ }^{y}$ Excluding irrigation. Season total is total of rainfall for June to September. Ithaca, N.Y., average rainfall for this period is $360 \mathrm{~mm}$.

${ }^{\mathrm{x}} \mathrm{All}$ amendments banded into 3-ft-wide pumpkin rows.

${ }^{\text {w} D i l m u n ~ H i l l ~ s i t e ~ a l s o ~ r e c e i v e d ~ l i m i n g ~ b e f o r e ~ t i l l a g e ~ a n d ~} 300 \mathrm{~kg} \cdot \mathrm{ha}^{-1}$ bone meal $(0-4.8-0$ total \% N-P-K) banded into pumpkin rows.

'Fine, illitic, mesic Glossaquic Hapludalfs.

"Fine-loamy, mixed, superactive, mesic Fluvaquentic Eutrudepts.

tFine-loamy, mixed, active mesic Oxyaquic Glossudalfs.

sFine-loamy, mixed, active, mesic Aeric Epiaqualfs.

Lana vetch(LV) strips were broadcast seeded at $101 \mathrm{~kg} \cdot \mathrm{ha}^{-1}$ and LV/R plots at $90 / 78 \mathrm{~kg} \cdot \mathrm{ha}^{-1}$, and incorporated with a tine harrow or similar implement. Once cover crops were seeded, weeds were not removed from the strips. Pumpkins were direct seeded at $0.61 \mathrm{~m}$ in-row spacing with $2.74 \mathrm{~m}$ between rows ['Merlin' in 2000 (Harris Moran, Modesto, Calif.); 'Tom Fox' in 2001 (Johnny's, Winslow, Maine)]. 'Merlin'was not used in 2001 because it is very susceptible to bacterial wilt, which caused a crop failure at one on-farm site in 2000 (not included here). 'Tom Fox' was a more resistant substitute of similar fruit size and vining habit. Each treatment was a single row with fifteen pumpkin plants, and 1.83-m-wide cover crop, BG, or WD strips and guard rows of pumpkins on each side. Loy et al. (1987) found a 1.1-m strip sufficient to prevent yield reduction of winter squash by perennial living mulches, so a 0.92 -m-wide strip for each pumpkin row was kept weed free through cultivation and hand weeding.

Cover crop strips were mowed to decrease competitive effects on pumpkins from the interseeded cover strips. In 2000, covers weremowed once with a weed trimmer at the time of vetch flowering, at a height of $45 \mathrm{~cm}$. In 2001, covers were rotary-mowed each time they reached 30 $\mathrm{cm}$, to a height of $10 \mathrm{~cm}$, except for the Freeville site where a flail mower was used. Depending on site and seeding date, this required between zero and three mowings.

Overhead irrigation was provided at a level intended to keep pumpkin plants in the bareground controls from severe drought stress, in order to reveal differences in water use between treatments. Irrigation totaled $1.25 \mathrm{~cm}$ at Dilmun Hill (one irrigation), $2.5 \mathrm{~cm}$ at Freeville (one irrigation), zero $\mathrm{cm}$ at Trumansburg, and $4.6 \mathrm{~cm}$ at Lansing (two irrigations). These relatively small amounts of irrigation brought water status of all sites to within the range of average rainfall for the area (Table 1) and allowed distinguishing differences between control and cover strip treatments.

Pumpkins were harvested twice to determine total yield for the harvest period, a representative practice for direct-marketed pumpkins. Marketable yield was calculated on a per-hectare basis, excluding misshapen fruit. At Dilmun Hill, the cool, wet early season in 2000 and poor-quality seed resulted in a poor stand. We transplanted greenhouse seedlings to fill gaps and excluded transplants from yield data so that yield treatment means were based on direct-seeded plants of equal age.

Total aboveground biomass in cover strips was sampled before the first mowing to assess effects on pumpkin yield due to biomass production by cover strips. All plants in four randomly placed $0.2-\mathrm{m}^{2}$ rectangular quadrats were cut at ground level, sorted by species, oven dried and weighed for determination of dry biomass. Weed biomass as a percent of the total was calculated to assess impacts on weeds, and weed biomass of the WD control was used to assess weed pressure at three sites. Due to time constraints, at the fourth site (Freeville) weed pressure was described qualitatively rather than by sampling the WD cover strip.

Nicholson and Wien (1983) demonstrated that yield reduction in vegetables with living mulches was directly correlated with biomass production by the living mulch. To analyze competitive effects of cover strips on the pumpkin crop with respect to cover seeding date, linear correlationwas determined between pumpkin yield and cover strip biomass at $30 \mathrm{~d}$ after pumpkin seeding (DAP). Yield and cover biomass were both normalized to the maximal value for each site. Since cover biomass could not always be sampled exactly at 30 DAP, and since rapid growth of covers at this time in the season could introduce errors, we corrected the biomass sampled near 30 DAP using an expolinear crop growth model (Ishag and Dennett, 1998).

Plant $\mathrm{N}$ status at pumpkin fruit set was measured by sampling the fifth fully expanded leaf on the main runner for five randomly selected plants in each plot. Leaves were dried at $60{ }^{\circ} \mathrm{C}$ for 1 week and ground to pass a size 40 mesh in a Wiley mill. Samples of about $3 \mathrm{mg}$ were combusted in a $\mathrm{C}$ and $\mathrm{N}$ analyzer and the combusted gas mixture analyzed for $\mathrm{N}$ using gas chromatography (NC 2100 analyzer; CE Instruments, Rodano, Italy). The integrated chromatography curve from retention of gases in the column was converted to $\mathrm{N}$ concentration using a standard curve generated with atropine and apple leaf samples of known $\mathrm{N}$ concentration.

Soil samples to $15 \mathrm{~cm}$ were obtained in pumpkin rows and cover strips to determine competition for soil nitrate between cover crops and pumpkins at Trumansburg and Lansing. Soil was sampled at the beginning of vine run, at least once during vine run and fruit set, and once at the end of the season (6 July, 25 July, 24 Aug., and 16 Oct. at Trumansburg; 19 July, 9 Aug., and 10 Oct. at Lansing). Samples were immediately placed on ice, frozen within $6 \mathrm{~h}$, and remained frozen until analysis, when they were thawed and sieved to $2 \mathrm{~mm}$. A water extract was prepared by shaking $7 \mathrm{~g}$ soil in 30 $\mathrm{g}$ deionized water for $25 \mathrm{~min}$ and filtering. The filtrate was analyzed for nitrates using nitration of salicylic acid and colorimetry against standards of known nitrate concentration (Cataldo et al., 1975). A spectrophotometer (UV-1601; Shimadzu, Braintree, Mass.) was used to measure absorptance of processed filtrates at $550 \mathrm{~nm}$. To standardize nitrate concentrations to the dry weight of soil, gravimetric moisture contents were also determined by drying soil in an oven at $105^{\circ} \mathrm{C}$ for $48 \mathrm{~h}$.

To measure soil water status, gypsumblocks (Delmhorst, Towaco, N.J.; methods in Campbell and Gee, 1986) were placed at $25 \mathrm{~cm}$ depth in the same treatments selected for soil sampling. Blocks were installed at Lansing at the onset of pumpkin vine run, centered on the pumpkin row and also $46 \mathrm{~cm}$ into the cover crop plots ( 92 $\mathrm{cm}$ from the center of the pumpkin rows). Two blocks per location were installed in each plot, except for the WD and LV-R B-till treatments, where only one block per location was installed. At Trumansburg, a high rainfall site, blocks were placed in mid-August, at the beginning of fruit set, and only in the rows. A soil water potential calibration curve for gypsum blocks had been previously developed using a pressure plate 


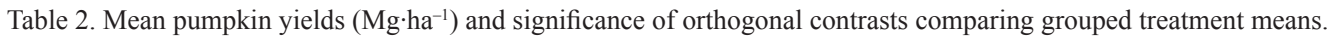

\begin{tabular}{|c|c|c|c|c|}
\hline \multirow{2}{*}{$\begin{array}{l}\text { Treatment } \\
\text { means }\end{array}$} & \multicolumn{4}{|c|}{ Site } \\
\hline & Dilmun Hill & Freeville & Lansing & Trumansburg \\
\hline Lana vetch & $6.1 \mathrm{cde}^{\mathrm{z}}$ & $27.5 \mathrm{~b}$ & $9.8 \mathrm{~d}$ & $25.8 \mathrm{~cd}$ \\
\hline Lana vetch-rye, tilled in & $\mathrm{NA}^{\mathrm{y}}$ & NA & $24.9 \mathrm{~b}$ & $39.3 \mathrm{~b}$ \\
\hline \multicolumn{5}{|l|}{ Same-seeded } \\
\hline Lana vetch & $9.0 \mathrm{abcd}$ & $33.3 \mathrm{~b}$ & $16.7 \mathrm{~cd}$ & $33.6 \mathrm{bc}$ \\
\hline Lana vetch-rye & 6.8 bcde & $28.3 \mathrm{~b}$ & $19.5 \mathrm{bc}$ & $25.2 \mathrm{~cd}$ \\
\hline Lana vetch-rye & $11.4 \mathrm{ab}$ & $53.3 \mathrm{a}$ & $32.2 \mathrm{a}$ & $55.5 \mathrm{a}$ \\
\hline Bare-ground control & $10.8 \mathrm{abc}$ & $53.3 \mathrm{a}$ & $32.9 \mathrm{a}$ & $50.6 \mathrm{a}$ \\
\hline Weedy control & $2.5 \mathrm{e}$ & $25.9 \mathrm{~b}$ & $17.2 \mathrm{~cd}$ & $18.8 \mathrm{~d}$ \\
\hline Overall ANOVA $P$ value for treatments & $P \leq 0.01$ & $P \leq 0.001$ & $P \leq 0.001$ & $P \leq 0.001$ \\
\hline \multicolumn{5}{|l|}{ Orthogonal contrasts } \\
\hline Early season cover biomass vs. no early season biomass ${ }^{\mathrm{x}}$ & 5.92 vs. $11.6^{* * *}$ & 29.6 vs. $52.0^{* * *}$ & 16.9 vs. $34.2^{* * *}$ & 26.8 vs. $52.3^{* * *}$ \\
\hline After seeded vs. bare ground & NS & NS & NS & NS \\
\hline Lana vs. lana-rye within before- and same-seeded covers & NS & NS & NS & 29.7 vs. $21.7^{*}$ \\
\hline Lana vs. lana-rye $\times$ before vs. same seeded covers & NS & NS & NS & NS \\
\hline
\end{tabular}

${ }^{2}$ Mean separation within each column by Duncan's new multiple range test $(P \leq 0.05)$.

'NA = not applicable: before-tilled in treatment not planted at this site.

×(LV B, LVR B, LV S, LVR S, WD) vs. (BG, LV A, LVR A).

"WD vs. (LV B, LVR B, LVR B-till, LV S, LVR S).

'LVR B-till vs. (LV B, LVR B, LV S, LVR S).

${ }^{*, * * * * * *}$ Significance of contrast at the levels $P \leq 0.05,0.01$, and 0.001 respectively.

Table 3. Weed biomass as a percent of total cover strip biomass, and biomass in weedy controls at four farm sites.

\begin{tabular}{|c|c|c|c|c|}
\hline \multirow[b]{3}{*}{ Factor } & \multicolumn{4}{|c|}{ Weed biomass of total cover strip biomass (\%) } \\
\hline & \multicolumn{4}{|c|}{ Site } \\
\hline & Dilmun Hill & Freeville & Lansing & Trumansburg \\
\hline \multicolumn{5}{|l|}{ Seeding date } \\
\hline Before $^{z}$ & $82 \mathrm{a}^{\mathrm{y}}$ & 6 & $33 \mathrm{a}$ & $38 \mathrm{ab}$ \\
\hline Same & $51 \mathrm{~b}$ & 3 & $21 \mathrm{a}$ & $55 \mathrm{a}$ \\
\hline After & $22 \mathrm{c}$ & 10 & $7 \mathrm{~b}$ & $3 c$ \\
\hline Significance & $\leq 0.001^{\mathrm{x}}$ & NS & 0.001 & $\leq 0.001$ \\
\hline \multicolumn{5}{|l|}{ Cover type } \\
\hline Lana & 59 & 8 & $24 \mathrm{a}$ & 39 a \\
\hline Lana-rye & 64 & 4 & $14 \mathrm{~b}$ & $19 \mathrm{~b}$ \\
\hline Significance & NS & NS & $P \leq 0.001$ & $P \leq 0.001$ \\
\hline \multicolumn{5}{|c|}{ Weed dry biomass in weedy control $\left(\mathrm{g} \cdot \mathrm{m}^{-2}\right)$} \\
\hline Broadleaf weeds & $393(50)^{\mathrm{w}}$ & $---v$ & $111(25)$ & $232(29)$ \\
\hline Grass weeds & $72(15)$ & --- & $26(13)$ & $19(19)$ \\
\hline Days to sampling & 84 & & 56 & 38 \\
\hline
\end{tabular}

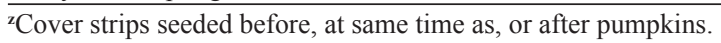

'Mean separation within each column by Duncan's new multiple range test at $P \leq 0.05$.

${ }^{x}$ Significance $P$ value of seeding date and cover type within two-factor ANOVA.

"Figure in parentheses is standard error.

"Weedy control treatment not sampled at Freeville but was rated visually as less than at Lansing.

apparatus (Soil Moisture Equipment, Goleta, Calif.). Blocks were read in the field at 2- to 5-d intervals.

Data were subjected to analysis of variance (ANOVA). Orthogonal contrasts (Little and Hills, 1978) were used to determine significance of cover type, seeding date, and comparisons between the cover treatments and the WD and BG controls. Mean separation was with Duncan's new multiple range test. An ANOVA including all sites was performed onyield data (Gomezand Gomez, 1984) to determine the appropriateness of combining sites in the yield analysis. Percent weed biomass of the cover strips was compared using a two-way ANOVA (seeding date and cover type as factors) with the SAS Proc GLM (SAS Institute, Cary, N.C.), after arcsine-square root transformation of percent biomass data. For data on soil moisture from gypsum blocks, a repeated-measurements ANOVA was performed using STATVIEW statistical software (Abacus Concepts, Berkeley, Calif.)

\section{Results and Discussion}

Yield and cover strip biomass. Significant interaction between farm and treatment $(\mathrm{F}=3.27$, $P<0.001)$ required a separate ANOVA on yield data from each site (Table 2). However, across all sites, bare-ground and after-seeded treatments without cover strip biomass early in pumpkin growth had higher yields than treatments with cover-strip biomass at this time (WD, beforeand same-seeded treatments). At Trumansburg and Lansing in 2001, same-seeded treatments yielded higher than before-seeded treatments.
The order of yield (before $<$ same $<$ after) is most likely due to preempting of resources by earlier-emerging plants, as described by Harper (1977). The highest yields at Freeville and Trumansburg qualified as excellent compared to average New York State pumpkin harvests (Reiners, 2004).

Pumpkin yields from LV treatments did not differ from those of LV-R treatments at any site (Table 2), which indicated that inclusion of the non-legume rye in the cover strips did not change their competitive effect. In weed-free cover crop strips between vegetable crops, Biazzo and Masiunas (2000) found white clover to be less competitive than other living mulches. However, our cover strips were mixtures of vetch, fast-growing annual weeds, and rye (where seeded), all of which were capable of quickly drawing down soil resources. Additionally, strips without rye had greater weed biomass (Table 3) that may have obscured any effect of lana vetch fixing atmospheric $\mathrm{N}$ rather than taking up soil $\mathrm{N}$.

For all sites, pumpkin yield was negatively correlated with biomass production of the cover strips at 30 DAP (Fig. 1; max cover biomass calculated using expolinear crop growth model was $3.1,2.0,4.0$, and $4.0 \mathrm{Mg} \cdot \mathrm{ha}^{-1}$ at FR, LN, $\mathrm{TB}$, and $\mathrm{DH}$ respectively). This correlation was consistent with cover crops' preempting resources (e.g., water and/or nutrients) from pumpkins in early growth. Freeville's yield was less correlated with early season cover biomass than for other sites probably because flail mowing was more suppressive to beforeseeded covers than rotary mowing at other sites, leading to equivalent yields in before- and same-seeded treatments (Table 2). Similarly, yields for LV-R B-till treatments were poorly correlated because cover strips were tilled in and did not compete with pumpkins after tillage. Seeding and tillage dates of cover strips relative to pumpkin seeding had a stronger impact than species composition on competitiveness of cover strips with pumpkins.

Weed biomass. Broadleaf weeds dominated 
weed biomass at all sites (Table 3). At Freeville, percent weed biomass was low in all cover strips and did not differ between seeding dates. At sites with greater weed pressure than at Freeville (Table 3), seeding date of cover strips had a

significant effect on percent weed biomass. At these three sites, after-seeded cover strips had the lowest weed biomass of the three seeding dates, probably because the weed seedbank was depleted during weeding and tillage previous to

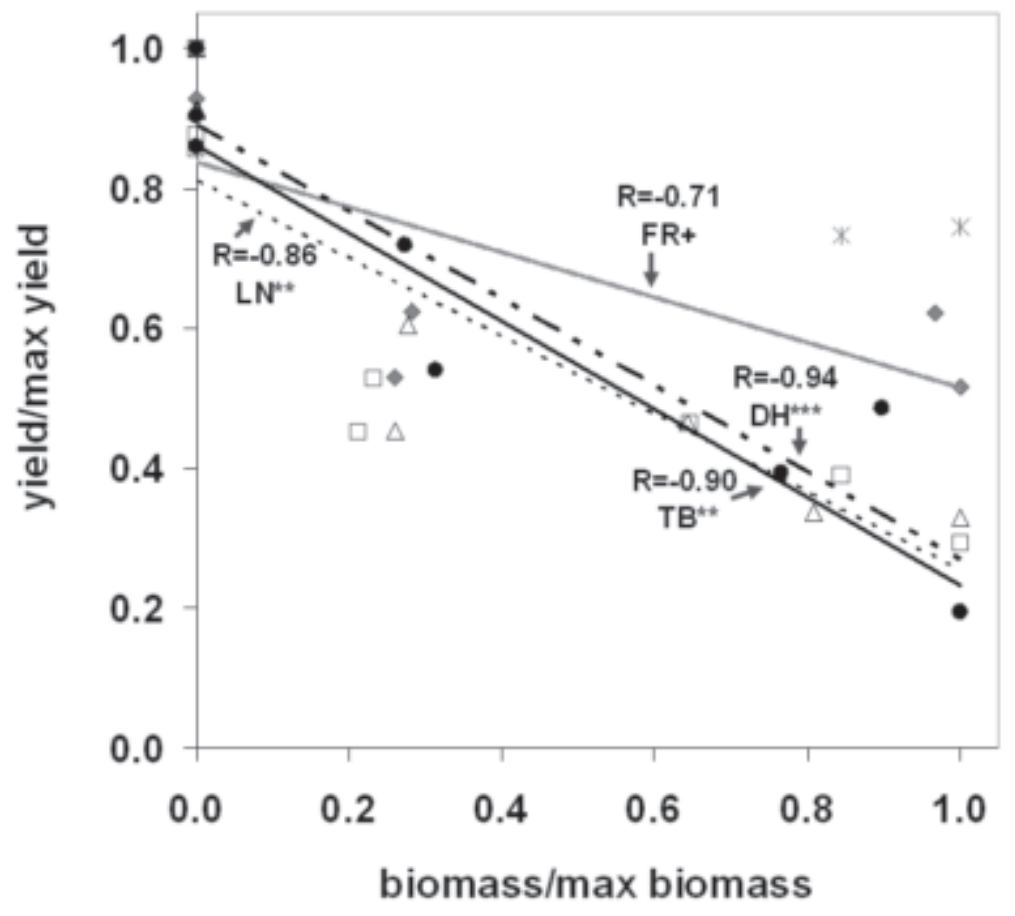

- Freeville (FR)

- Dilmun Hill (DH)

- Dilmun Hill

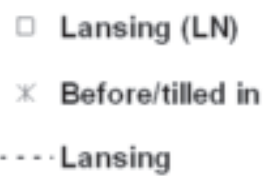

$\triangle$ Trumansburg (TB)

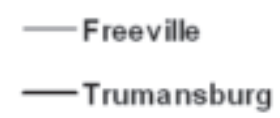

Fig. 1. Pumpkin yield normalized to maximum yield for each site, vs. normalized cover strip biomass in the first $30 \mathrm{~d}$ of pumpkin growth. Lines are linear regressions on data for each farm site and do not take into account LV-R B-till treatments. ${ }^{+, * * *, * * *}$ Significance of regressions at $P \leq 0.10,0.05,0.01$, and 0.001 .

Table 4. Percent $\mathrm{N}$ in pumpkin fifth leaf and significance of orthogonal contrasts comparing grouped treatment means.

\begin{tabular}{|c|c|c|}
\hline \multirow{2}{*}{$\begin{array}{l}\text { Treatment } \\
\text { means }\end{array}$} & \multicolumn{2}{|c|}{ Site } \\
\hline & Lansing & Trumansburg \\
\hline \multicolumn{3}{|l|}{ Before-seeded } \\
\hline Lana vetch & $4.24 \mathrm{c}^{\mathrm{z}}$ & $3.65 \mathrm{c}$ \\
\hline Lana vetch-rye & $4.50 \mathrm{bc}$ & $3.97 \mathrm{bc}$ \\
\hline Lana vetch-rye, tilled in & $5.11 \mathrm{ab}$ & $4.95 \mathrm{a}$ \\
\hline \multicolumn{3}{|l|}{ Same-seeded } \\
\hline Lana vetch & $4.94 \mathrm{ab}$ & $4.36 \mathrm{~b}$ \\
\hline Lana vetch-rye & $4.89 \mathrm{abc}$ & $4.13 \mathrm{bc}$ \\
\hline \multicolumn{3}{|l|}{ After-seeded } \\
\hline Lana vetch & $5.42 \mathrm{a}$ & $5.01 \mathrm{a}$ \\
\hline Lana vetch-rye & $5.50 \mathrm{a}$ & $4.97 \mathrm{a}$ \\
\hline Bare-ground control & $5.27 \mathrm{a}$ & $5.28 \mathrm{a}$ \\
\hline Weedy control & $5.31 \mathrm{a}$ & $3.52 \mathrm{~d}$ \\
\hline Overall ANOVA $P$ value for treatments & $P \leq 0.05$ & $P \leq 0.001$ \\
\hline \multicolumn{3}{|l|}{ Orthogonal contrasts } \\
\hline Early season cover biomass vs. no early season biomass ${ }^{y}$ & 4.83 vs. $5.40^{* *}$ & 4.10 vs. $5.09^{* * * *}$ \\
\hline After-seeded vs. bare ground & NS & NS \\
\hline Lana vs. lana-rye within after-seeded & NS & NS \\
\hline Weedy control vs. before- and same-seeded cover strips ${ }^{\mathbf{x}}$ & 5.31 vs. $4.74^{*}$ & 3.52 vs. $4.21^{* * * *}$ \\
\hline Lana-rye before-tilled vs. other before- and same-seeded covers ${ }^{\mathrm{w}}$ & 5.11 vs. $4.64^{+}$ & 4.95 vs. $4.03^{* * *}$ \\
\hline Before- vs. same-seeded covers & 4.37 vs. $4.92^{*}$ & 3.81 vs. $4.25^{*}$ \\
\hline Lana vs. lana-rye within before- and same-seeded covers & NS & NS \\
\hline Lana vs. lana-rye $\times$ before- vs. same-seeded covers & NS & NS \\
\hline
\end{tabular}

${ }^{2}$ Mean separation within each column by Duncan's new multiple range test at $P \leq 0.05$.

y(LV B, LVR B, LV S, LVR S, WD) vs. (BG, LV A, LVR A).

${ }^{x}$ WD vs. (LV B, LVR B, LVR B-till, LV S, LVR S).

${ }^{w}$ LVR B-till vs. (LV B, LVR B, LV S, LVR S).

${ }^{+, *, * * * * * *}$ Significance of contrast at the levels $P \leq 0.1,0.05,0.01$, and 0.001 respectively. establishing after-seeded treatments. AtDilmun Hill, a site with heavy weed pressure, a similar reduction in percent weed biomass was also seen between before- and same-seeded covers. Cover type (LV vs. LV-R) had varied effects across farms. At Freeville (low weed pressure) and Dilmun Hill (high weed pressure) there was no difference between cover types in suppressing weeds. At Trumansburg and Lansing with moderate weed pressure, vetch-rye was superior to vetch in suppressing weeds. This difference in weed suppression was likely due to the higher total seeding rate of the LV-R strips in better competing with weeds, but could also be related to other factors specific to rye. Considering the yield results presented above, after-seeding of LV-R strips with high seeding rates into pumpkins is a promising practice, especially where good previous weed management has sufficiently lowered weed pressure.

Pumpkin leaf N concentration. Fifth leaf N concentration at fruit set was significantly lower in treatments at Trumansburg and Lansing with early-season biomass in the cover strips (Table 4). Pumpkin yield was significantly, and positively, related to leaf $\mathrm{N}$ concentration, suggesting that nitrogen was a factor of competition at both sites (Fig. 2). However, only at Trumansburg was leaf $\mathrm{N}$ in the lowest-yielding treatments $<4 \%$, a value for $\mathrm{N}$ sufficiency in pumpkins at fruit set (Mills and Jones, 1996). These apparent sufficiency levels along with a smaller range of leaf $\mathrm{N}$ concentrations at Lansing (Table 4) suggest that competition for $\mathrm{N}$ was less important at Lansing than at Trumansburg.

Soil nitrate concentration-cover strips. Results for soil nitrate concentration support the conclusions that $\mathrm{N}$ competition reduced pumpkin yield for treatments with early-season cover biomass, and also that $\mathrm{N}$ was less important as a factor of competition at Lansing, the drier site. Nitrate levels in soil are known to result from nitrification of labile $\mathrm{N}$ in organic amendments and native soil organic matter, which add nitrate to the soil pool, and uptake by plants along with leaching below the sampled depth, which reduce nitrate levels (Brady and Weil, 1999). Nitrate is the dominant form of nitrogen taken up by plants in warm, aerated, high-fertility agricultural soils (Schimel and Bennett, 2004), and its concentration is used here along with leaf $\mathrm{N}$ concentration discussed above to assess the impact of cover strips on pumpkin $\mathrm{N}$ status.

In cover strips at Trumansburg (Fig. 3), soil nitrate levels on the first sampling date (28DAP) were negatively correlated with the age of cover strips $(\mathrm{BG}>$ same-planted $>$ before-planted and $\mathrm{WD}, R=-0.95)$, suggesting that plant uptake was the primary explanation for lower nitrate concentration. High levels of nitrate in the BG treatment would have made soil there vulnerable to leaching but would have given pumpkin plants producing roots in the cultivated BG strips ample nitrate for uptake, as seen in the higher BG leaf $\mathrm{N}$ later in the season (Table 4).

At the second sampling date, $12 \mathrm{~d}$ after Trumansburg's LV-R B-till cover strips were tilled, soil nitrate content in the newly-tilled cover strips had risen to equal that of the $\mathrm{BG}$ treatment, while same- and before-seeded treat- 
Fig. 2. Regression of total pumpkin yield against percent total leaf $\mathrm{N}$ at fruit set. Trumansburg regression significant at $P \leq 0.001$; Lansing regression significant at $P \leq$ 0.01 .

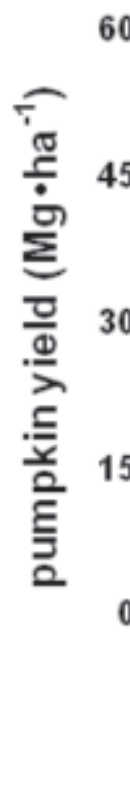

0

.

3.0

4.0

5.0

6.0

Leaf $\% \mathrm{~N}$, fifth expanded leaf

- Trumansburg $\square$ Lansing

\section{Days after pumpkin seeding}

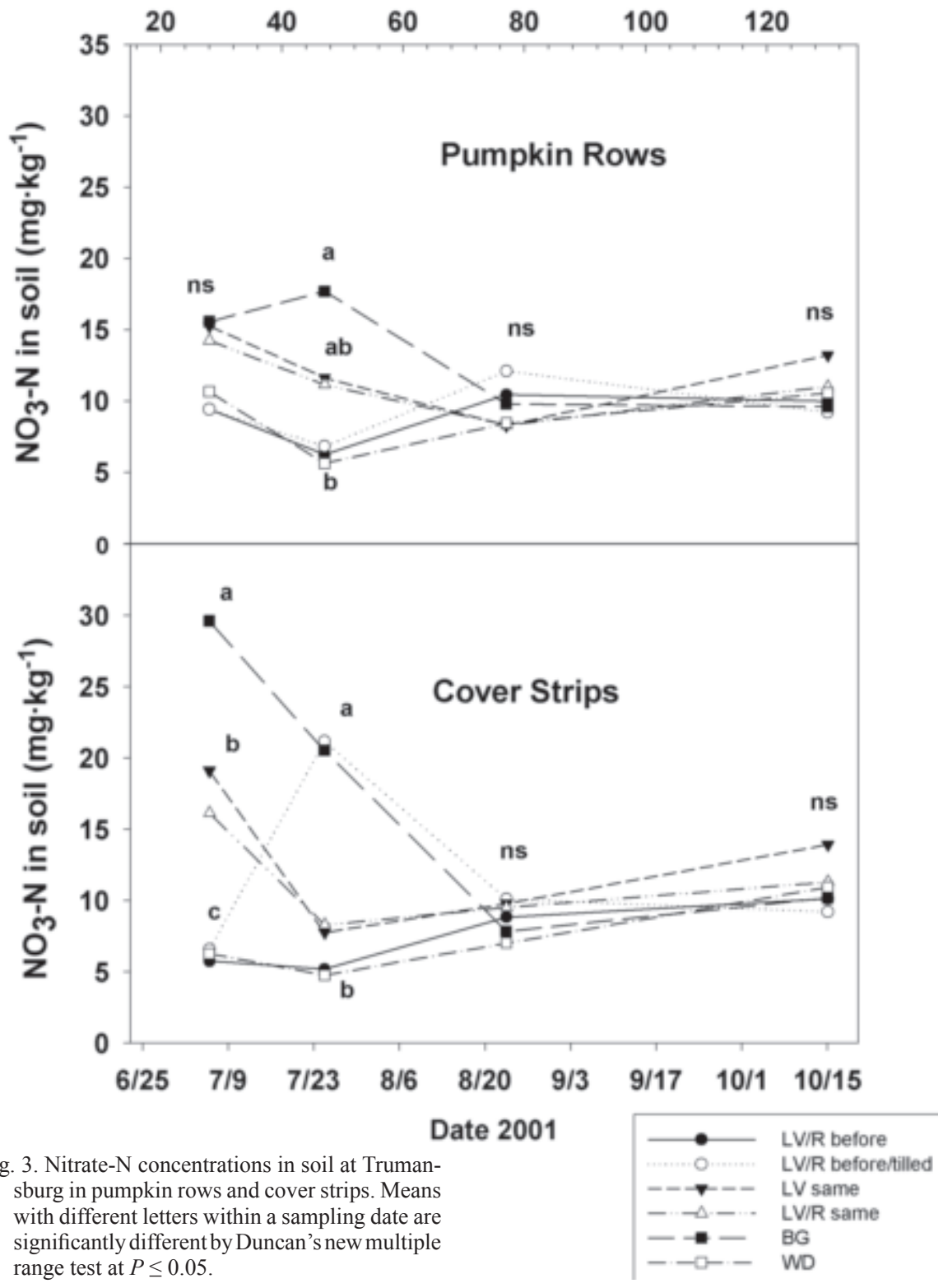

ments had lower and equivalent nitrate levels. The rise in LV-R B-till nitrate concentration after tillage may have been due the cessation of uptake by the tilled-in strip. Mineralization of organic $\mathrm{N}$ from incorporation of almost $3 \mathrm{Mg} \cdot \mathrm{ha}^{-1}$ succulent rye and vetch (data not shown) probably also contributed to the rise in soil nitrate $12 \mathrm{~d}$ after tillage. Since LV-R B-till soil nitrate levels did not exceed those in the BG treatment, only moderate mineralization of incorporated covers had occurred by this date. In other studies, peak nitrate release from incorporated cover crops occurred well after $12 \mathrm{~d}$ (Stivers and Shennan, 1991, Hasegawa et al., 1999). Soil nitrate levels in the cover strips at Trumansburg were markedly lower for the third sampling date (Fig. 3), with no differences between treatments. These results may be due to leaching of nitrate beyond the sampled soil depth by rainfall, or to uptake by the full pumpkin-cover strip canopy present in all plots by this date. At season end, cover strip soil nitrate concentrations were again not different.

Soil nitrate levels in cover strips at Lansing showed similar patterns to those at Trumansburg (Fig. 4). Weedy cover strips at Lansing had higher soil nitrate levels than at Trumansburg, possibly reflecting lower weed biomass at Lansing (Table 3).

At Trumansburg, averaged soil nitrate concentrations for the first two sampling dates in cover strips (Fig. 3) were highly correlated with pumpkin yield $\left(\mathrm{R}=0.97, \operatorname{yield}\left(\mathrm{Mg} \cdot \mathrm{ha}^{-1}\right)=1.68\right.$ $\times[$ nitrate-N $\left.]\left(\mathrm{mg} \cdot \mathrm{kg}^{-1}\right)+9.51\right)$. These averaged soil nitrate levels (Fig. 3) were also positively correlated $(R=0.93)$ with leaf N concentrations sampled at 75 DAP soon after these soil samples were taken (Table 4). These results show that before- and same-seeded covers reduced yield at Trumansburg by taking up soil nitrate that was then not available to the pumpkin crop. At Lansing, correlation of soil nitrate levels for these dates with pumpkin yield was lower $\left(R=0.84\right.$, yield $\left(\mathrm{Mg} \cdot \mathrm{ha}^{-1}\right)=0.92 \times[$ nitrate-N] $\left(\mathrm{mg} \cdot \mathrm{kg}^{-1}\right)+5.90$; slopes of regression lines different for two sites at $P=0.07$ ). This was consistent with pumpkin leaf $\mathrm{N}$ concentrations, which were also less strongly correlated with pumpkin yield at Lansing (Fig. 2).

Soil nitrate concentration-pumpkin rows. Soil nitrate levels in pumpkin rows at Trumansburg were lower than in cover strips and varied less among treatments than levels in cover strips (Fig. 3). The only sampling date with significant differences was 45 DAP, 2 weeks after a sidedress application of composted chicken manure to rows in all treatments. At this time WD, $\mathrm{LV}-\mathrm{R}$ $\mathrm{B}$ and LV-R B-till rows had significantly lower soil nitrate than the bare ground control. The two same-seeded cover treatments had intermediate values. These differences at Trumansburg suggest that in treatments with cover strips, soil nitrate in rows moved to cover strips where it was taken up by rye, vetch, or weeds (plausible due to high rainfall at Trumansburg and nitrate's mobility with soil water). Alternatively, more $\mathrm{N}$-limited pumpkin plants (Table 4) in beforeseeded and WD treatments might have taken up more soil nitrate in rows because they could not access soil nitrate in the occupied cover strips. Regardless of the mechanism, this result 
again shows $\mathrm{N}$ limitation of pumpkin plants in treatments with cover strip biomass, even after midseason application of compost. Similar, but lower, differences in soil nitrate occurred at Lansing for this sampling date, where levels were higher in BG pumpkin rows than in other sampled treatments (Fig. 4).

These results provide additional evidence that before- and same-seeded cover strips reduced nitrogen availability to the pumpkin crop. At both sites, interseeded vetch and rye that was present early in the season reduced the supply of soil nitrate not only in the cover strips, but also in the pumpkin rows. This reduced nitrogen supply led to reduced yields, especially at Trumansburg.

Soil water potential. Soil water potential at Trumansburg was adequate for crop growth on all dates, and was not different among treatments (mean: $-0.22 \mathrm{MPa}$; range: -0.66 to $-0.05 \mathrm{MPa}$ ). The adequate soil moisture resulted from above-average rainfall at Trumansburg (Table 1).

At Lansing, a repeated-measurement ANOVA of water potential data showed significant treatment by sampling date interactions. Because of interactions, separate ANOVAs and orthogonal contrasts (not shown) were run for a range of dates through the season, which confirm the trends depicted in Figs. 5 and 6.

Differences in soil water status occurred at Lansing between treatments with early-season biomass in the cover strips $(\mathrm{LV}-\mathrm{R} \mathrm{B}, \mathrm{LV} \mathrm{S}$, LV-R S, WD) and LV-R A and BG treatments without this biomass. During the driest parts of the season, LV-R B and WD treatments were drier than LV S and LV-R S treatments, and WD treatments were also significantly drier than LV-R B treatments (Figs. 5 and 6).

There were no soil water potential differences between same-seeded treatments with and without rye. This is not surprising, since

\section{Days after pumpkin seeding}

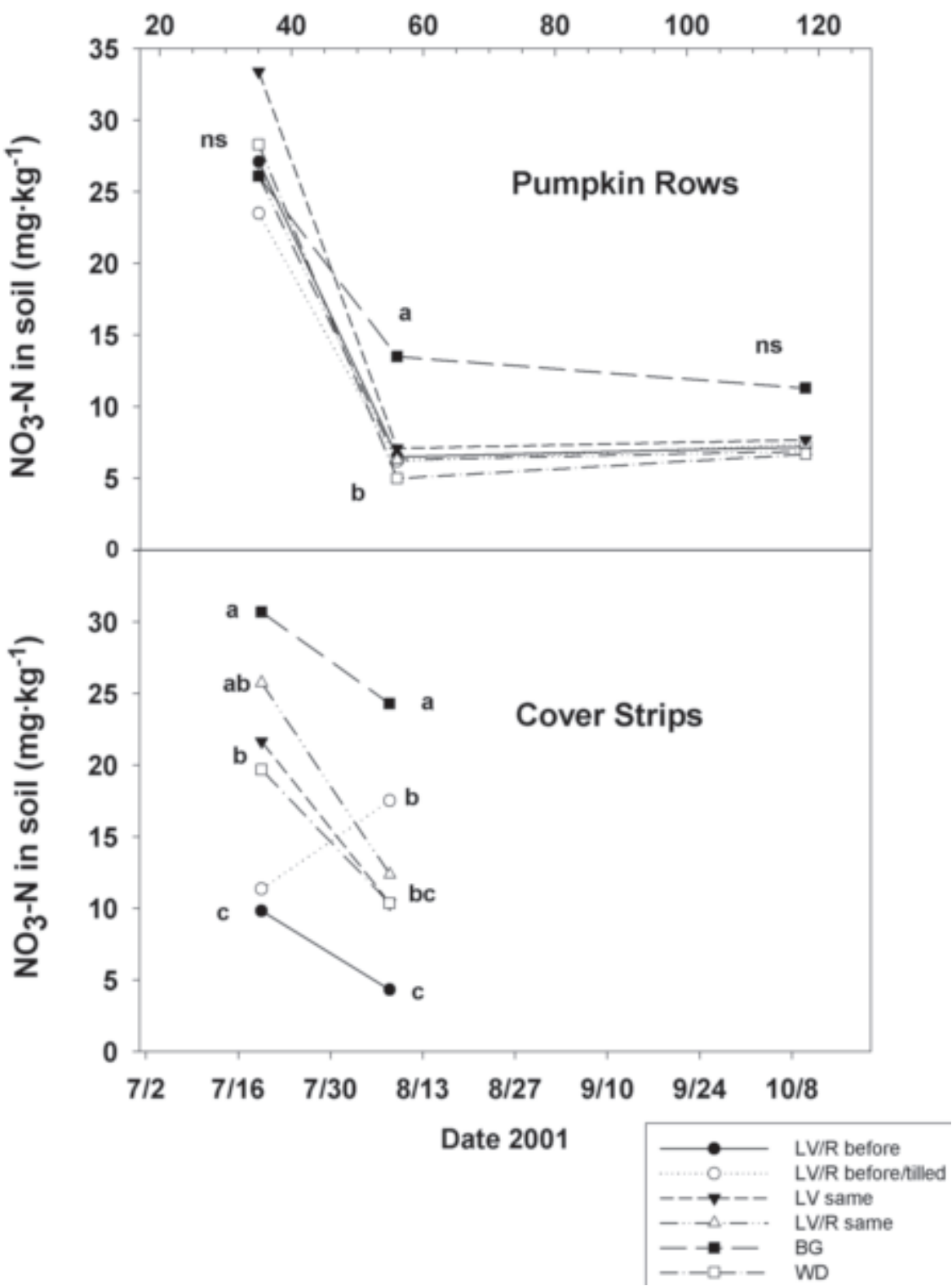

Fig. 4. Nitrate-N concentrations in soil at Lansing in pumpkin rows and cover strips. Means with different letters within a sampling date are significantly different by Duncan's new multiple range test at $P \leq 0.05$.

both cover strip types contained lana vetch, whose close relative hairy vetch (Vicia villosa Roth) was found to have a high water use rate and low water use efficiency (ratio of biomass production to water uptake) among legume cover crop species (Zachariassan and Power, 1991). Also, LV treatments were weedier than LV-R treatments at Lansing (Table 3), and weeds may have taken the place of rye in the LV cover strips, creating similar water uptake for the strip as a whole.

These patterns largely explain differences in yields at Lansing, with the exception that the WD treatment had equivalent yields to the same-seeded treatments although its water status was lower on many dates. The weed/pumpkin competitive interaction may have differed from the cover strip-pumpkin interaction, although it was not possible in this experiment to determine why WD pumpkins yielded higher than the soil water potential in mid-season would seem to indicate.

\section{Summary}

For the pumpkin-rye-vetch interseeding strategy described, reductions in pumpkin yield can be minimized by eliminating or avoiding large amounts of biomass production by cover strips during the first $30 \mathrm{~d}$ of pumpkin growth. This assumes that after-seeded cover crops are able to successfully establish as a cover crop under the pumpkin canopy, which was observed here.

Using rye and vetch as before- or sameseeded intercrops with pumpkins is not feasible from the standpoint of pumpkin yield, a result that would probably also apply to other widely spaced cucurbit crops. Cover strips can be planted at 30 DAP with no effect on pumpkin yield, while tillage of preexisting cover crops at this date gives moderate yield reductions. Further research might test whether cover strip interseeding or tillage could occur sooner after pumpkin seeding while maintaining acceptable pumpkin yields and low weed biomass. Different widths of the main crop and cover strips could also be investigated to expand the range of appropriate interseeding dates and adapt practices to available farm implements.

Soil nitrate and soil moisture results from two organic farm sites showed that cover strips established early in the season preempted a limiting resource at each site ( $\mathrm{N}$ at Trumansburg, water at Lansing) and reduced pumpkin yields. This suggests that additional irrigation of the pumpkin crop would not completely mitigate yield reductions from before- and same-seeded cover strips, since $\mathrm{N}$ would replace water as a dominant factor of competition under increased irrigation. Additional organic nitrogen fertilization might also raise yields with before- and same-seeded strips to acceptable levels but is probably not in accordance with responsible nutrient management.

\section{Literature Cited}

Abdul-Baki,A.A. and J.R. Teasdale. 1993. Ano-tillage tomato production system using hairy vetch and subterranean clover mulches. HortScience 28:106-108.

Akobundu, I.O. and B.N. Okigbo. 1984. Preliminary evalu- 
ation of ground covers for use as a live mulch in maize production. Field Crops Res. 8:177-186.

Biazzo, J. and J.B. Masiunas. 2000. The use of living mulches for weed management in hot pepper and okra. J. Prod. Agr. 16:59-79.

Brady, N.C. and Weil, R.R. 1999. The nature and properties of soils. 12th ed. Prentice Hall, Upper Saddle River, N.J.

Brainard, D.C. and Bellinder, R.R. 2004. Weed suppression in a broccoli-winter rye interseeding system. Weed Sci. 52:281-290

Campbell, G.S., and G.W. Gee. 1986. Water potential: miscellaneousmethods, p. 619-633. In:A. Klute(ed.). Methods of soil analysis. Part I: Physical and mineralogical methods. 2nd ed. Amer. Soc. Agron., Madison, Wis.

Cataldo, D.A., M. Haroon, L.E. Schrader, and V.L. Youngs.
1975. Rapid colorimetric determination of nitrate in plant tissue by nitration of salicylic acid. Commun. Soil Sci. Plan. 6:71-80.

Creamer, N.G. and M.A. Bennett. 1997. Evaluation of cover crop mixtures for use in vegetable production systems. HortScience 32:866-870.

Drinkwater, L.E., R.R. Janke, and L. Rossoni-Longnecker. 2000. Effects of tillage intensity on nitrogen dynamics and productivity in legume-based grain systems. Plant Soil 227:99-113.

Gomez,K.A. andA.A. Gomez. 1984. Statistical procedures for agricultural research. 2nd ed. Wiley, New York, N.Y.

Grubinger, V.P. and P.L. Minotti. 1990. Managing white clover living mulch for sweet corn production with partial rototilling. Amer. J. Altern. Agr. 5:4-12.

\section{Days after planting}

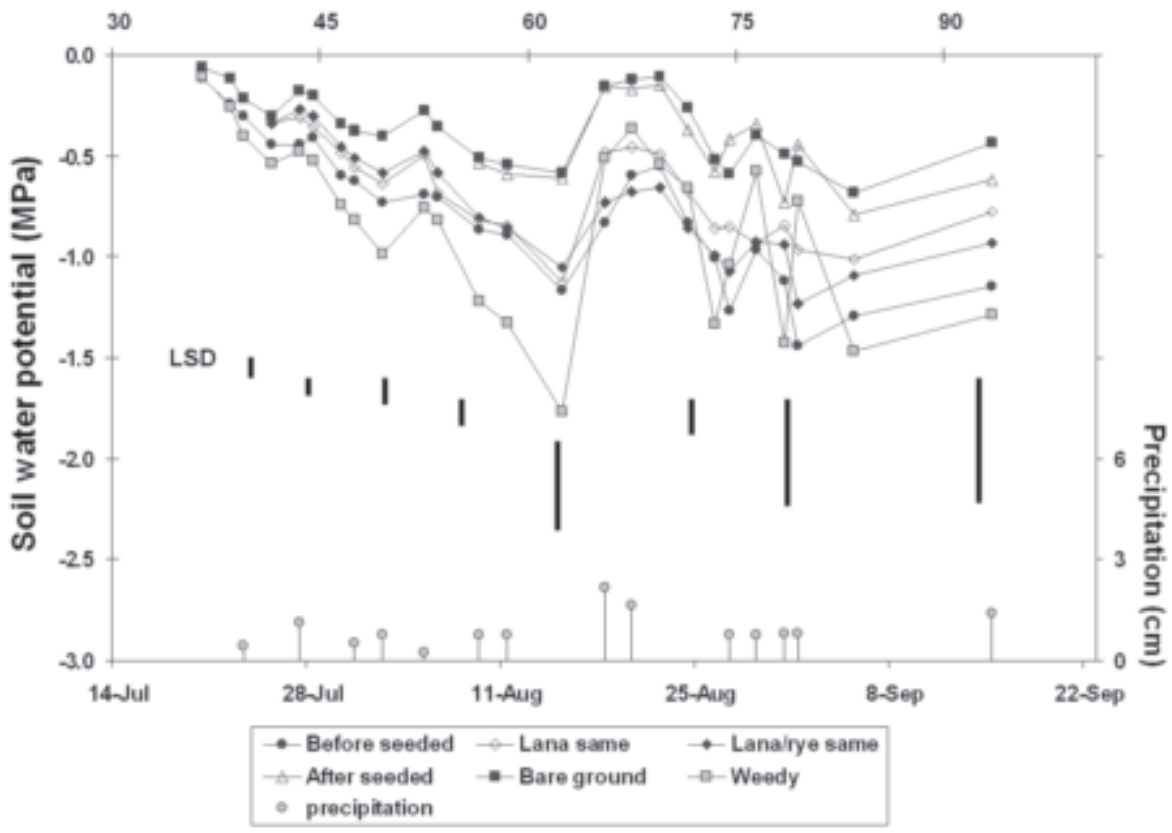

Fig. 5. Precipitation and soil water potential at $25 \mathrm{~cm}$ depth in pumpkin rows for Lansing. Vertical bars represent least significant difference between treatments $(P \leq 0.05)$.

\section{Days after planting}

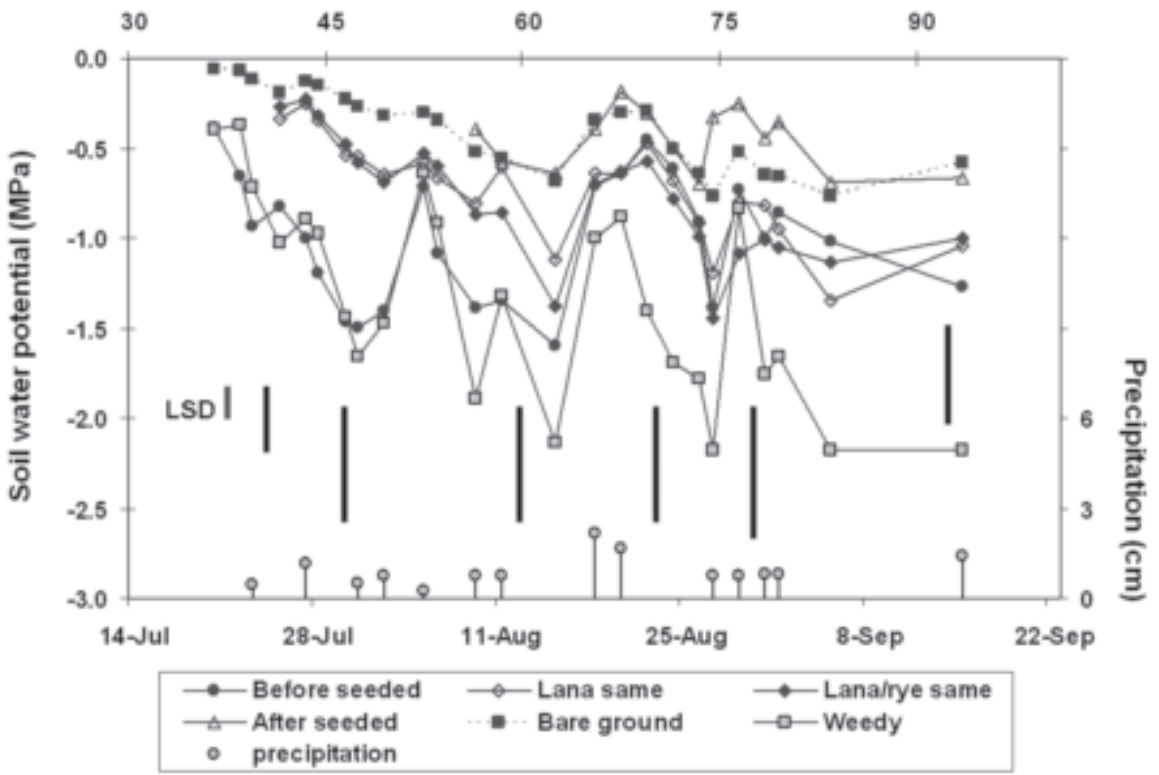

Fig. 6. Precipitation and soil water potential at $25 \mathrm{~cm}$ depth in cover strips for Lansing. Vertical bars represent least significant difference between treatments $(P \leq 0.05)$.

Harper, J.L. 1977. Population biology of plants. 1st ed. Academic Press, London.

Hasegawa, H., J.M. Labavitch, A.M. McGuire, D.C. Bryant, and R.F. Denison. 1999. Testing CERES model predictions of $\mathrm{N}$ release from legume cover crop residue. Field Crops Res. 63:255-267.

Holderbaum, J.F., A.M. Decker, J.J. Meisinger, F.R. Mulford, and L.R. Vough. 1990. Fall-seeded legume cover crops for no-tillage corn in the humid east. Agron. J. 18:117-124.

Hughes, B.J. and R.D. Sweet. 1979. Living mulch: a preliminary report on grassy cover crops interplanted with vegetables. Proc. N.E. Weed Sci. Soc. 33:109.

Ishag, K.H.M. and M.D. Dennett. 1998. Use of the expolinear growth model to analyse the growth of faba peas, peas and lentils at three densities: fitting the model. Ann. Bot. 82:497-505.

Little, T.M. and F.J.Hills. 1978. Agricultural experimentation. 1st ed. Wiley, New York, N.Y.

Loy, S.J.W., L.C. Peirce, G.O. Estes, and O.S. Wells. 1987. Productivity in a strip tillage vegetable production system. HortScience 22:415-417.

Mills, H.A. and J.B. Jones, Jr. 1996. Plant analysis handbook II. Micro Macro Publ., Jefferson City, Mo.

Mohler, C.L. 1995.Aliving mulch (white clover)/dead mulch (compost) weed control system for winter squash. Proc. N.E. Weed Sci. Soc. 49:5-10.

Nelson, W.A., B.A. Kahn, and B.W. Roberts. 1991. Screening cover crops for conservation tillage systems for vegetables following spring plowing. HortScience 26:860-862.

Nicholson, A.G. and H.C. Wien. 1983. Screening of turfgrasses and clovers for use as living mulches in sweet corn and cabbage. J. Amer. Soc. Hort. Sci. 108:1071-1076.

Northeast Organic Farming Association of New York. 2001. Organic farm and handling/processing certification standards and administrative procedures. (NOFA-NY, Binghamton, N.Y.

Paine, L.K. and H. Harrison. 1993. The historical roots of living mulch and related practices. HortTechnology $3: 137-142$.

Puget, P. and L.E. Drinkwater. 2001. Short-term dynamics of root-and shoot-derived carbon from a leguminous green manure. Soil Sci. Soc. Am J. 65:771-779.

Rajalahti, R.M., R.R. Bellinder, and M.P. Hoffmann. 1999. Time of hilling and Interseeding affects weed control and potato yield. Weed Sci. 47:215-225.

Reiners, S. 2004. Average yields for vegetable crops grown in New York State.Accessed 15 December, 2004 (available online athttp://www.hort.cornell.edu/extension/commercial/vegetables/online/product/aveyield.html).

Sarrantonio, M. 1992. Opportunities and challenges for the inclusion of soil-improving crops in vegetable production systems. HortScience 27:754-758.

Schimel, J.P and J. Bennett. 2004. Nitrogen mineralization: challenges of a changing paradigm. Ecology 85:591-602.

Scott, T.W., J. Mt. Pleasant, R.F. Burt, and D.J. Otis. 1987. Contributions of ground cover, dry matter, and nitrogen from intercrops and cover crops in a corn polyculture system. Agron. J. 79:792-798.

Stivers, L.J. and C. Shennan. 1991. Meeting the nitrogen needs of processing tomatoes through winter cover cropping. J. Prod. Agric. 4:330-335.

Stivers, L.J., D.C. Brainard, G.S. Abawi, and D.W. Wolfe. 1999. Cover crops for vegetable production in the northeast. Cornell Coop. Ext. Bul. 244.

Wiles, L.D., R.D. William, and G.D. Crabtree. 1989. Analyzing competition between a living mulch and a vegetable crop in an interplanting system. J. Amer. Soc. Hort. Sci. 114:1029-1034.

Yaffa, S., U.M. Sainju, and B.P. Singh. 2000. Fresh market tomato yield and soil nitrogen as affected by tillage, cover cropping, and nitrogen fertilization. HortScience 35:1258-1262.

Zachariassen, J.A. and J.F. Power. 1991. Growth rate and water use by legume species at three soil temperatures. Agron. J. 83:408-413. 